\title{
Using Organic Amendments to Decrease Bulk Density and Increase Macroporosity in Compacted Soils
}

\author{
Angela Rivenshield and Nina L. Bassuk
}

\begin{abstract}
Samples of compacted sandy loam and clay loam soil were amended with organic matter: sphagnum peat or food waste compost. Amendments were incorporated into the soil samples at $0 \%, 10 \%, 33 \%, 50 \%$, and $75 \%$ on a volume-tovolume basis. Changes in bulk density and macroporosity resulting from amendation were measured. In every permutation but one, macroporosity increased and bulk density decreased to below root-restricting thresholds. These results held true for the half of the samples that were manually recompacted. Differences between the amendments were not significant. Amendation with sufficient amounts of sphagnum peat or food waste compost alleviates compaction, creating an environment more conducive for root growth.
\end{abstract}

Key Words. Aeration porosity; amendments; bulk density; compaction; compost; macroporosity; root growth; root restriction; sphagnum; woody plants.

Trees planted into compacted urban soils tend to decline rapidly because of two factors: insufficient macroporosity, which results in poor drainage and aeration, and high bulk density, which impedes root movement through the soil (Craul 1992).

Macroporosity and bulk density are useful indicators of soil compaction. Macroporosity refers to the arrangement of solid particles in a soil and is low when, like in compacted soils, particles lie close together. In most soils, $0.01 \mathrm{~mm}$ (0.0004 in) or less micropores comprise the majority of total pore space (Aubertin and Kardos 1965). Macropores in this experiment were defined as those pores larger than $0.78 \mathrm{~mm}$ (0.031 in); they enable rapid drainage through the soil profile.

Bulk density is the mass of dry soil per unit of bulk volume, including the pore space. Soils with a high proportion of solids to pore space have higher bulk densities. A normal range of bulk densities for clay is 1.0 to $1.6 \mathrm{mg} / \mathrm{m}^{3}$ and a normal range for sand is 1.2 to $1.8 \mathrm{mg} / \mathrm{m}^{3}$ (Aubertin and Kardos 1965) with potential root restriction occurring at $\geq 1.4$ $\mathrm{mg} / \mathrm{m}^{3}$ for clay and $\geq 1.6 \mathrm{mg} / \mathrm{m}^{3}$ for sand (Aubertin and Kardos 1965; Corley 1984). Many compacted urban soils have been shown to have a bulk density of 1.6 to $2.0 \mathrm{mg} / \mathrm{m}^{3}$. Most trees grow best in well-aggregated, well-drained soils with bulk densities less than $1.5 \mathrm{mg} / \mathrm{m}^{3}$ (Craul 1985).

Although soil compaction and its deleterious effects can be mitigated with the addition of soil amendments (Whitcomb 1979; Spomer 1983; Brady 1990), several experiments have questioned the value of amending tree-planting holes. One study concluded that there were no significant improvements to plant growth in amended soils (Pellet 1971). Other studies found that amendment was advantageous to the growth of shore juniper (Juniperus conferta) (Corley 1984) and callery pear (Pyrus calleryana 'Redspire') (Day and Bassuk 1994) or that major inconsistencies were the result of variations in the organic matter batches used, not the actual amending process (Hodge 1995). The objective of this experiment was to reinvestigate amending compacted soils with organic matter to see if root-restricting conditions could be mitigated even after soil recompaction.

\section{MATERIALS AND METHODS}

\section{Soil Samples and Amendments}

Soil samples of two different textures-sandy loam and clay loam-were taken from disturbed fields in Ithaca, New York, U.S. The sandy loam was taken from the F.R. Newman Arboretum, Cornell University, where it had been dredged to make room for ponds and sculpted into earthen berms. The berm soil was severely compacted with bulk density as high as $1.9 \mathrm{mg} / \mathrm{m}^{3}$ and predictably poor drainage. The clay loam came from a Cornell agricultural field that had been purposefully compacted for a prior experiment. Both areas were chosen because of their highly disturbed natures, mimicking poor urban planting sites.

Particle size analysis of the sandy loam showed that it consisted of $48.8 \%$ sand, $8.6 \%$ clay, and $42.6 \%$ silt. The sand portion was well graded with many fine particles that could lend themselves readily to compaction. The clay loam con- 
sisted of $23.8 \%$ sand, $30.2 \%$ clay, and $46.0 \%$ silt; the sand was also well graded.

Two types of organic amendment were used: sphagnum peat and food waste compost. The sphagnum peat was $\mathrm{Ca}$ nadian stock, medium graded, and chosen because of its traditional use in the horticultural industry. The food waste compost - a 3 year composted stock of food waste, manure, wood chips, and sand-was donated by Ithaca College and was selected because of its potential usefulness to the industry. The amendments were analyzed for $\mathrm{pH}$, exchange acidity, and nutrient, organic matter, and moisture content.

\section{Procedure}

Gravel $2.5 \mathrm{~cm}$ (1 in) in diameter or larger was removed from soil samples as were any obvious clumps of organic matter. The soil was then divided and the appropriate amounts of sphagnum peat or food waste compost were added. The amendments were added to the soils at $0 \%, 10 \%, 33 \%, 50 \%$, and $75 \%$ on a volume-to-volume basis. Aquagro (Aquatrols Corp. of America, Paulsboro, NJ, U.S.) wetting agent was added to the peat samples at a rate of $0.06 \mathrm{~g}$ per sample. Each sample was contained within a $7.62 \mathrm{~cm} \mathrm{(3} \mathrm{in)} \times 10.16 \mathrm{~cm} \mathrm{(4}$ in) metal soil core ring.

Half of the samples were recompacted by 25 blows with a standard $38 \mathrm{~cm}(15 \mathrm{in}), 2.5 \mathrm{~kg}(5.5 \mathrm{lb})$ Proctor Hammer to yield ASTM $100 \%$ proctor density (Daddow and Warrington 1983). The compacted samples were wetted and brought to their plastic limit, the lowest moisture content at which a soil can no longer be deformed without cracking. To test for the plastic limit, samples were placed on a pressure cell apparatus and set to pressures of $1 \mathrm{kPa}, 2.5 \mathrm{kPa}, 5 \mathrm{kPa}, 10 \mathrm{kPa}, 20 \mathrm{kPa}$, and $40 \mathrm{kPa}$, reflecting a range from a very wet soil to a very dry soil. The samples were left at each pressure for 2 days, after which time they were tested for plasticity. Plasticity was achieved when soil ribbons the approximate consistency of putty were formed.

To assess large pore $(\geq 0.78 \mathrm{~mm}[\geq 0.03 \mathrm{in}])$ drainage, the samples were saturated in plastic vats over a period of 5 days. Water levels were raised slowly to prevent air entrapment. The samples then drained for $3 \mathrm{hr}$. Weights were taken before and after saturation and after drainage.

The drained samples were then placed on a pressure cell apparatus and pressurized to $10 \mathrm{kPa}$. Once equilibrium was reached, the samples were removed from the pressure cell apparatus and weighed. Those not to be compacted were resaturated using the procedure described. Those to be compacted were placed on a steel tray on a concrete floor for stability. A wooden disk of one-inch thickness was used for even distribution of the compactive force.

These samples were again resaturated. All resaturated samples were drained for $3 \mathrm{hr}$ and weighed. They were then placed into a laboratory oven and dried at $105^{\circ} \mathrm{C}\left(221^{\circ} \mathrm{F}\right)$ for $48 \mathrm{hr}$ after which the final dry weight was taken. Bulk den- sity, macroporosity, and total porosity were calculated as follows:

Bulk Density $=$ mass of dry soil/bulk volume

\section{Total porosity:}

Saturated weight - oven dry weight $=$ weight of water

Weight of water $\times$ Bulk Density $=$ Total Porosity

Weight of oven dry soil minus ring weight

\section{Macroporosity on a total soil volume basis:}

Saturated weight $-3 \mathrm{hr}$ weight

- weight of water lost after a $3 \mathrm{hr}$ drain

$3 \mathrm{hr}$ drained weight $=$ macroporosity on total soil volume basis ring volume

\section{Statistical Analysis}

Statistical analysis and evaluation was conducted using Minitab 10X for Macintosh. Analysis included curve estimation, pairwise comparisons, Tukey's and Dunnett's T3 significance tests, and one-way analysis of variance.

\section{RESULTS}

The results showed that both sandy loam and clay loam soils, when amended with peat or food waste compost, had lower bulk density and higher macroporosity than those not amended even after recompaction (Table 1). With one exception, the higher the rate of added amendment, the greater the change (Figures 1 through 8). Differences between amendments were not significant.

\section{Bulk Density}

\section{Sandy Loam}

The sandy loam samples with $0 \%$ amendment had a bulk density of $1.5 \mathrm{mg} / \mathrm{m}^{3}$ uncompacted, $1.8 \mathrm{mg} / \mathrm{m}^{3}$ compacted. The addition of $10 \%$ food waste compost did not significantly reduce the bulk density in either case; the addition of $10 \%$ peat did but only in uncompacted samples.

The addition of $33 \%$ food waste compost lowered the bulk density to $1.2 \mathrm{mg} / \mathrm{m}^{3}$ (20\% change) for uncompacted samples and $1.5 \mathrm{mg} / \mathrm{m}^{3}$ (17\% change) for compacted samples. When amended with $33 \%$ peat, the bulk density of the sandy loam decreased to $1.2 \mathrm{mg} / \mathrm{m}^{3}$ in uncompacted samples and 1.4 $\mathrm{mg} / \mathrm{m}^{3}$ in compacted samples, a $20 \%$ decrease in both cases. The decrease in bulk density brought the 33\% amended samples below the threshold for potential root restriction.

With the addition of $50 \%$ food waste compost, the bulk density decreased to $1.2 \mathrm{mg} / \mathrm{m}^{3}$ in uncompacted samples and to $1.4 \mathrm{mg} / \mathrm{m}^{3}$ in compacted samples. Peat amendment by $50 \%$ yielded the same decrease. 
Table 1. Bulk density and macroporosity of compacted sandy loam or clay loam samples amended with increasing percentages of food waste compost or peat ${ }^{2}$.

\begin{tabular}{|c|c|c|c|c|c|}
\hline Samples & Bulk density & Significance $^{\mathrm{yx}}$ & Macroporosity & Significance ${ }^{\mathrm{yx}}$ & $r^{2}$ \\
\hline Sandy loam/compacted & 1.76 & $a^{x}$ & 0.0207 & $a^{x}$ & \\
\hline Sandy loam/uncompacted & 1.51 & $b^{\mathrm{x}}$ & 0.0387 & $b^{\mathrm{x}}$ & \\
\hline Sandy loam $+10 \%$ compost/compacted & 1.68 & $\mathrm{a}$ & 0.0243 & $\mathrm{ab}$ & \\
\hline Sandy loam $+33 \%$ compost/compacted & 1.50 & $\mathrm{~b}^{\mathrm{y}}$ & 0.0267 & $b^{y}$ & \\
\hline Sandy loam $+50 \%$ compost/compacted & 1.42 & $\mathrm{~b}^{\mathrm{y}}$ & 0.0413 & $\mathrm{c}^{\mathrm{y}}$ & \\
\hline Sandy loam $+75 \%$ compost/compacted & 0.90 & $c^{y}$ & 0.0557 & $\mathrm{~d}^{\mathrm{y}}$ & 0.90 \\
\hline Sandy loam $+10 \%$ compost/uncompacted & 1.50 & $\mathrm{a}$ & 0.0277 & $\mathrm{a}$ & \\
\hline Sandy loam $+33 \%$ compost/uncompacted & 1.22 & $\mathrm{~b}^{\mathrm{y}}$ & 0.0400 & $\mathrm{~b}^{\mathrm{y}}$ & \\
\hline Sandy loam $+50 \%$ compost/uncompacted & 1.17 & $\mathrm{~b}^{\mathrm{y}}$ & 0.0517 & $\mathrm{c}^{\mathrm{y}}$ & \\
\hline Sandy loam $+75 \%$ compost/uncompacted & 0.83 & $c^{y}$ & 0.0627 & $d^{y}$ & 0.94 \\
\hline Sandy loam $+10 \%$ peat/compacted & 1.62 & $\mathrm{a}$ & 0.0323 & $\mathrm{~b}^{\mathrm{y}}$ & \\
\hline Sandy loam $+33 \%$ peat $/$ compacted & 1.38 & $\mathrm{~b}^{\mathrm{y}}$ & 0.0477 & $c^{y}$ & \\
\hline Sandy loam $+50 \%$ peat/compacted & 1.38 & $\mathrm{~b}^{\mathrm{y}}$ & 0.0543 & $\mathrm{~d}^{\mathrm{y}}$ & \\
\hline Sandy loam $+75 \%$ peat $/$ compacted & 0.62 & $c^{y}$ & 0.0620 & $\mathrm{e}^{\mathrm{y}}$ & 0.86 \\
\hline Sandy loam $+10 \%$ peat/uncompacted & 1.17 & $\mathrm{~b}^{\mathrm{y}}$ & 0.0460 & $\mathrm{~b}^{\mathrm{y}}$ & \\
\hline Sandy loam $+33 \%$ peat/uncompacted & 1.22 & $\mathrm{~b}^{\mathrm{y}}$ & 0.0510 & $\mathrm{~b}^{\mathrm{y}}$ & \\
\hline Sandy loam $+50 \%$ peat/uncompacted & 0.93 & $c^{y}$ & 0.0677 & $c^{y}$ & \\
\hline Sandy loam $+75 \%$ peat/uncompacted & 0.54 & $\mathrm{~d}^{\mathrm{y}}$ & 0.0710 & $\mathrm{c}^{\mathrm{y}}$ & 0.87 \\
\hline Clay loam/compacted & 1.84 & $a^{x}$ & 0.0125 & $a^{x}$ & \\
\hline Clay loam/uncompacted & 1.26 & $b^{x}$ & 0.0305 & $b^{x}$ & \\
\hline Clay loam $+10 \%$ compost/compacted & 2.36 & $\mathrm{a}$ & 0.0120 & $\mathrm{a}$ & \\
\hline Clay loam $+33 \%$ compost/compacted & 2.01 & $\mathrm{~b}^{\mathrm{y}}$ & 0.0213 & $\mathrm{~b}^{\mathrm{y}}$ & \\
\hline Clay loam $+50 \%$ compost/compacted & 1.61 & $c^{y}$ & 0.0257 & $\mathrm{~b}^{\mathrm{y}}$ & \\
\hline Clay loam $+75 \%$ compost/compacted & 1.28 & $\mathrm{~d}^{\mathrm{y}}$ & 0.0323 & $c^{y}$ & 0.69 \\
\hline Clay loam $+10 \%$ compost/uncompacted & 1.30 & $\mathrm{a}$ & 0.0323 & $\mathrm{a}$ & \\
\hline Clay loam $+33 \%$ compost/uncompacted & 1.10 & $\mathrm{~b}^{\mathrm{y}}$ & 0.0270 & $\mathrm{a}$ & \\
\hline Clay loam $+50 \%$ compost/uncompacted & 0.94 & $b c^{y}$ & 0.0290 & $\mathrm{a}$ & \\
\hline Clay loam $+75 \%$ compost/uncompacted & 0.85 & $c^{y}$ & 0.0337 & $\mathrm{~b}^{\mathrm{y}}$ & 0.85 \\
\hline Clay loam $+10 \%$ peat/compacted & 1.81 & $\mathrm{a}$ & 0.0190 & $\mathrm{a}$ & \\
\hline Clay loam $+33 \%$ peat $/$ compacted & 1.63 & $\mathrm{~b}^{\mathrm{y}}$ & 0.0327 & $b^{\mathrm{y}}$ & \\
\hline Clay loam $+50 \%$ peat $/$ compacted & 1.41 & $c^{y}$ & 0.0350 & $\mathrm{bc}^{*}$ & \\
\hline Clay loam $+75 \%$ peat $/$ compacted & 1.10 & $\mathrm{~d}^{\mathrm{y}}$ & 0.0430 & $c^{y}$ & 0.97 \\
\hline Clay loam $+10 \%$ peat/uncompacted & 1.15 & $a b$ & 0.0340 & $\mathrm{a}$ & \\
\hline Clay loam $+33 \%$ peat/uncompacted & 0.96 & $\mathrm{~b}^{\mathrm{y}}$ & 0.0403 & $\mathrm{~b}^{\mathrm{y}}$ & \\
\hline Clay loam $+50 \%$ peat/uncompacted & 0.76 & $c^{y}$ & 0.0377 & $\mathrm{~b}^{\mathrm{y}}$ & \\
\hline Clay loam $+75 \%$ peat/uncompacted & 0.53 & $\mathrm{~d}^{\mathrm{y}}$ & 0.0517 & $c^{y}$ & 0.98 \\
\hline
\end{tabular}

${ }^{\mathrm{z}}$ Half of the samples were recompacted after amendment.

${ }^{y}$ Significantly different than the unamended samples at alpha 0.05 .

${ }^{\mathrm{x}}$ Significantly different between unamended samples at alpha 0.05 .

Letters that are the same are not significantly different from one another.

With the addition of $75 \%$ food waste compost, the largest amount added, bulk density decreased to $0.8 \mathrm{mg} / \mathrm{m}^{3}$ in uncompacted samples and $0.9 \mathrm{mg} / \mathrm{m}^{3}$ in compacted samples. With $75 \%$ peat, bulk density decreased to $0.5 \mathrm{mg} / \mathrm{m}^{3}$ in uncompacted samples and $0.6 \mathrm{mg} / \mathrm{m}^{3}$ in compacted samples. At the $75 \%$ rate for food waste amendment, there was a $47 \%$ decrease in bulk density in uncompacted samples and a 50\% decrease in compacted samples. At the $75 \%$ rate for peat amendment, there was a $67 \%$ decrease in the bulk density of both uncompacted and compacted samples.

Linear regressions (Figures 1 through 8) show that significant reduction in bulk density occurred at lower rates of added amendment than the tested amounts reflected. For instance, in testing, compacted sandy loam samples showed a significant change at 33\% added peat, but the linear regressions show that bulk density fell below restricting levels when $20 \%$ peat was added. This trend holds true for all sample permutations.

\section{Clay Loam}

The clay loam samples with $0 \%$ amendment had a bulk density of $1.3 \mathrm{mg} / \mathrm{m}^{3}$ uncompacted and $1.8 \mathrm{mg} / \mathrm{m}^{3}$ compacted. The addition of $10 \%$ food waste compost actually increased the bulk density to $2.4 \mathrm{mg} / \mathrm{m}^{3}$ in compacted samples but made no significant change in uncompacted samples. 


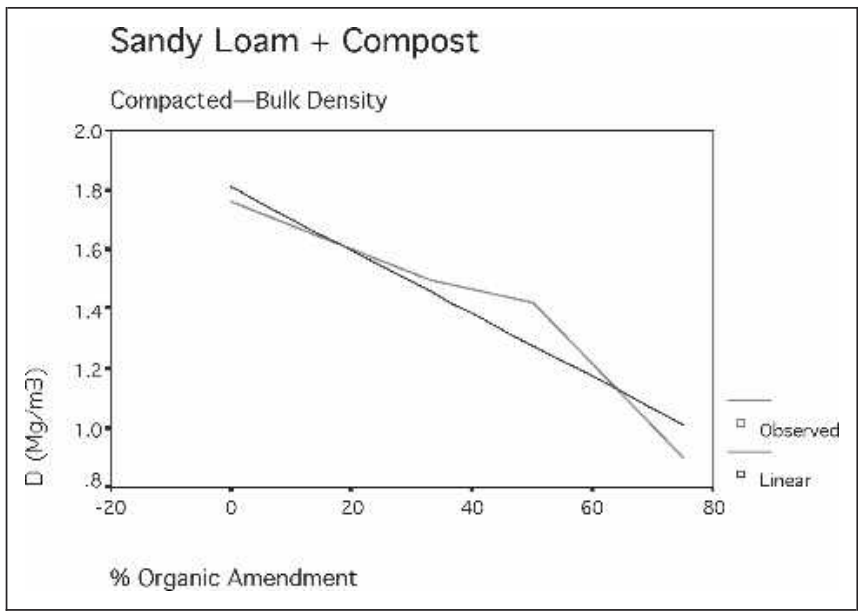

Figure 1. Linear regression for sandy loam and compost: bulk density.

The addition of $33 \%$ food waste compost lowered the bulk density to $1.1 \mathrm{mg} / \mathrm{m}^{3}$ for uncompacted samples $(15 \%$ decrease from unamended) and $2.0 \mathrm{mg} / \mathrm{m}^{3}$ for compacted samples. The latter reflects a decrease in bulk density from the $10 \%$ amended samples but an increase in bulk density from the unamended samples. This anomalous increase after amendment may be the result of sand within the food waste compost binding with the clay particles to create a greater density. With the addition of $33 \%$ peat amendment, bulk density decreased to $1.0 \mathrm{mg} / \mathrm{m}^{3}$ in uncompacted samples and $1.6 \mathrm{mg} / \mathrm{m}^{3}$ in compacted samples.

With incorporation of $50 \%$ food waste compost, bulk density decreased to $1.0 \mathrm{mg} / \mathrm{m}^{3}$ in uncompacted samples and to $1.6 \mathrm{mg} / \mathrm{m}^{3}$ in compacted samples. With $50 \%$ added peat, bulk density decreased to $0.8 \mathrm{mg} / \mathrm{m}^{3}$ in uncompacted samples and $1.4 \mathrm{mg} / \mathrm{m}^{3}$ in compacted samples. For clay loam, the $50 \%$

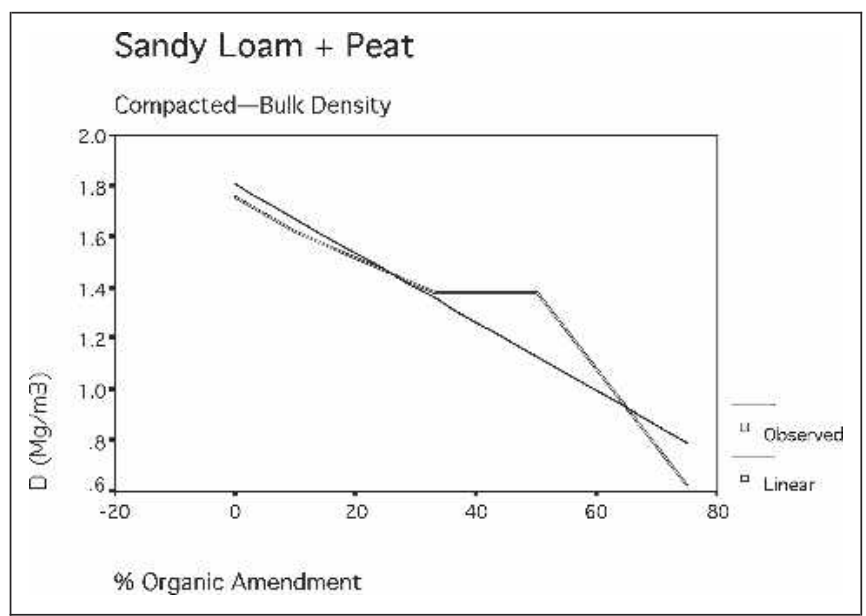

Figure 2. Linear regression for sandy loam and peat: bulk density.

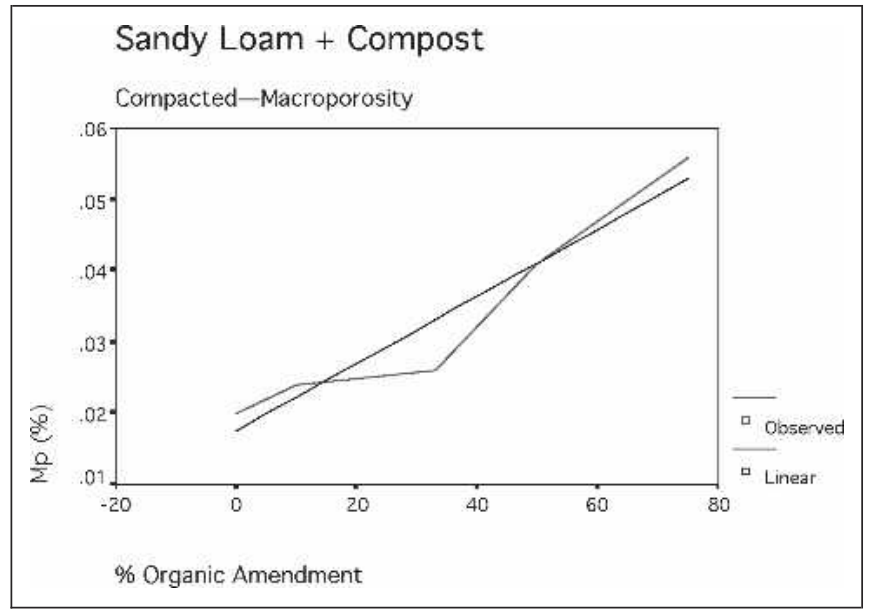

Figure 3. Linear regression for sandy loam and compost: macroporosity.

amendment rate yielded the first bulk density readings below root restricting levels.

With the addition of $75 \%$ food waste compost, bulk density decreased to $0.9 \mathrm{mg} / \mathrm{m}^{3}$ ( $31 \%$ change over unamended) in uncompacted samples and $1.3 \mathrm{mg} / \mathrm{m}^{3}$ (28\% change) in compacted samples. With the addition of $75 \%$ peat, bulk density decreased to $0.5 \mathrm{mg} / \mathrm{m}^{3}$ (62\% change over unamended) in uncompacted samples and $1.1 \mathrm{mg} / \mathrm{m}^{3}$ (38\% change) in compacted samples.

Linear regressions show that, in most cases, the volumes of added amendments at which significant change in bulk density occurs may be slightly lower than the actual rates tested. For instance, in testing the sandy loam samples, a significant decrease in bulk density occurred at $33 \%$ added compost, but the linear regressions suggest that the significant rate may actually be $22 \%$ to $25 \%$ added amendment.

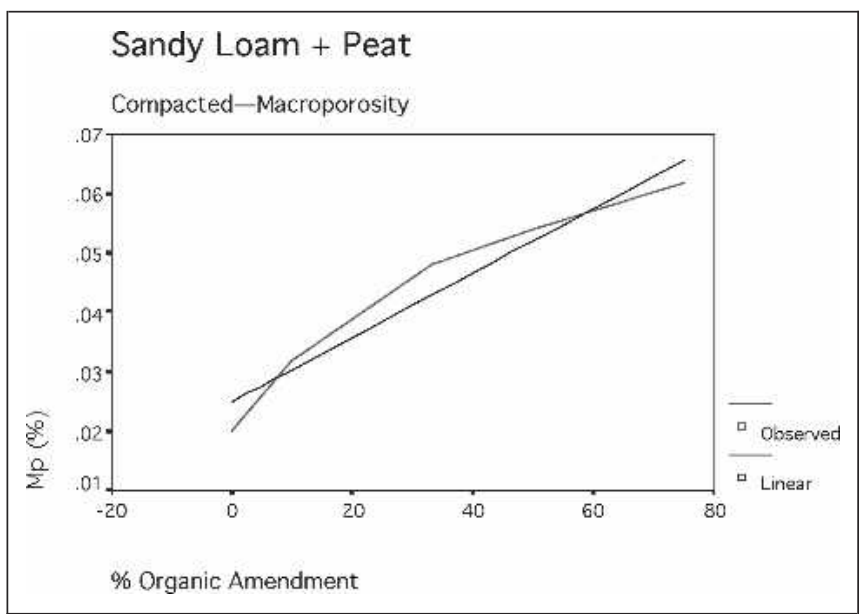

Figure 4. Linear regression for sandy loam and peat: macroporosity. 


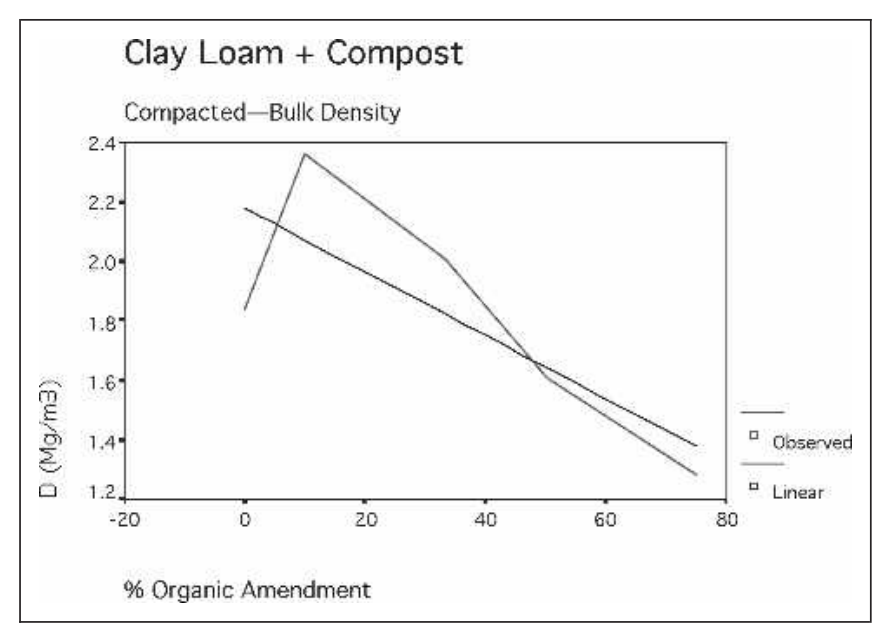

Figure 5. Linear regression for clay loam and compost: bulk density.

\section{Macroporosity}

Because there are no horticulturally based standards for macroporosity ranges, it was difficult to predict when potential root restricting levels of macroporosity may have been reached or alleviated. Therefore, unlike the bulk density data that could be measured against root restricting thresholds, the macroporosity data were evaluated for general trends.

\section{Sandy Loam}

The unamended sandy loam samples had a macroporosity of 0.04 (4\% of the volume was occupied by macropores) when uncompacted and 0.02 when compacted. The addition of $10 \%$ food waste compost reduced the macroporosity of the uncompacted samples to 0.03 but made no change to the compacted samples. The addition of $10 \%$ peat increased the macropo-

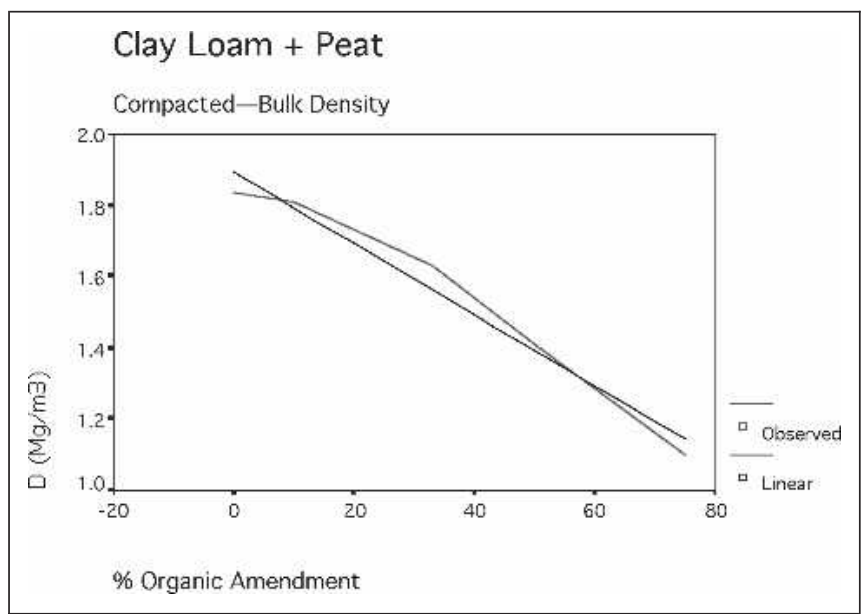

Figure 6. Linear regression for clay loam and peat: bulk density.

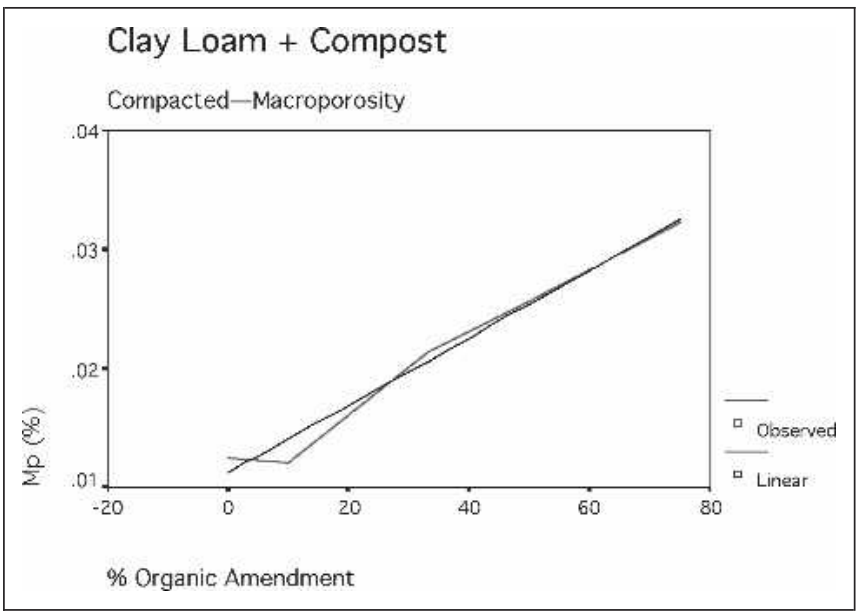

Figure 7. Linear regression for clay loam and compost: macroporosity.

rosity of both: uncompacted samples to 0.05 and compacted samples to 0.03 .

The addition of $33 \%$ food waste compost did not change the macroporosity of uncompacted samples but increased the macroporosity of the compacted samples to 0.03 . With $33 \%$ added peat, macroporosity increased to 0.05 for both the uncompacted and compacted samples.

When $50 \%$ food waste compost was added, macroporosity stayed the same (0.05) for uncompacted samples but decreased to 0.04 in compacted samples. When $50 \%$ peat was added, macroporosity increased to 0.07 for uncompacted samples and increased to 0.05 for compacted samples.

With 75\% amendment of food waste compost, macroporosity increased to 0.06 in both uncompacted and compacted samples. When $75 \%$ peat was added, macroporosity in-

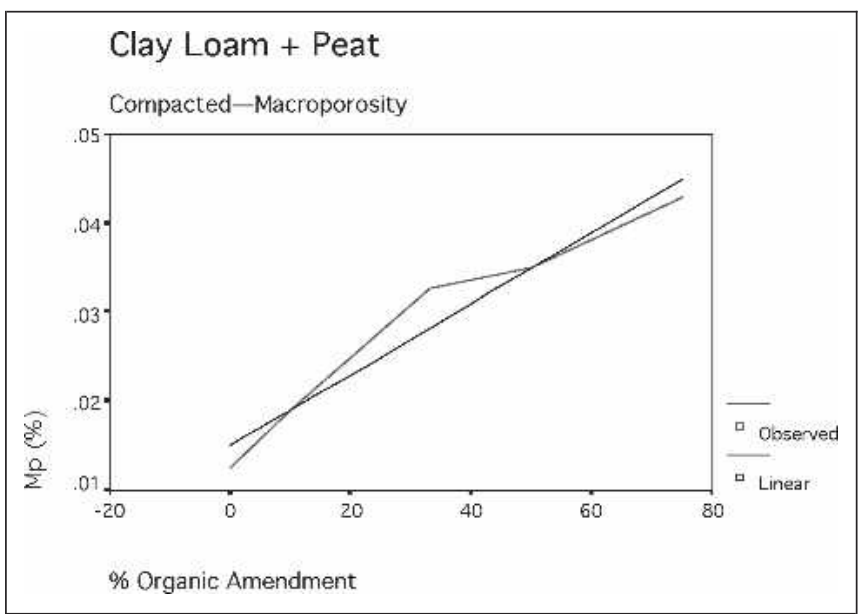

Figure 8. Linear regression for clay loam and peat: macroporosity. 
creased to 0.07 in the uncompacted samples and 0.06 in the compacted samples. From unamended sandy loam to $75 \%$ added amendment (food waste compost or peat), macroporosity of the compacted samples increased 200\%. Macroporosity of the uncompacted samples increased 50\% with $75 \%$ added food waste compost and macroporosity increased $75 \%$ with $75 \%$ added peat.

\section{Clay Loam}

For the clay loam samples, there were no significant increases in the macroporosity of the uncompacted samples when amended with any rate of food waste compost. However, the compacted clay loam samples showed an increase in macroporosity - from 0.01 to 0.02 - when $33 \%$ food waste compost was added, an increase to 0.03 when $50 \%$ food waste compost was added, and macroporosity held steady at 0.03 with the addition of $75 \%$ food waste compost.

The addition of peat to the clay loam increased macroporosity steadily in both uncompacted and compacted soil samples. In uncompacted soil, macroporosity increased from 0.03 at $10 \%$ added peat, to 0.04 at $33 \%$ and $50 \%$ added peat, and to 0.05 at $75 \%$ added peat. In compacted soil, macroporosity increased from 0.02 at $10 \%$, to 0.03 at $33 \%$, and to 0.04 at $50 \%$ and $75 \%$ added peat. The overall increase in macroporosity from unamended clay loam to clay loam with $75 \%$ added peat was $67 \%$ in uncompacted samples and $100 \%$ in compacted samples.

\section{DISCUSSION}

This investigation showed that the addition of organic amendment (at least 33\% for sandy loam and 50\% for clay loam) to a compacted soil reduced bulk density to below root restricting thresholds and increased macroporosity significantlymore than $100 \%$ in some cases. Sphagnum peat was marginally more effective at lowering bulk density and increasing macroporosity than food waste compost, probably because of the deleterious "particle nesting" effects of the added sand in the food waste compost.

For both bulk density and macroporosity, linear regressions showed that, in most cases, the volume of amendment at which significant change occurred might be slightly lower than the actual volumes tested.

The results suggest that amending a clay loam might not produce as many physical changes as amending a sandy loam. To amend a clay loam, at least $50 \%$ by volume sphagnum peat should be added to reduce bulk density to below root restricting thresholds; macroporosity may still be low. Fifty percent by volume is a large quantity of amendment and may create other problems, including severe shrinkage. Because this shrinkage could allow water to pool, if amending clay loam with $50 \%$ organic matter, one should select plants that tolerate poor drainage.
The results of this study confirm some of the existing literature while challenging some studies that question the value of amending tree-planting sites. Pellet (1971) stated that there were no significant improvements to plant growth in amended soils. Our research shows a distinct difference between amended and unamended soil samples. Although this was a purely soil-focused investigation, one could hypothesize that with increased soil macroporosity and decreased bulk density, tree roots would establish more readily, enhancing plant growth.

Hodge (1995) found a significant improvement in plant growth when a clay soil was amended with organic matter. He found inconsistencies with amending clay soil that parallel our inconsistencies with clay samples amended with food waste compost. In both cases, the sand content of the compost may have decreased macroporosity. However, bulk density decreased, and bulk density may play a more crucial role in root growth than macroporosity. If this is the case, then the clay loam was effectively remediated through the addition of organic amendment.

Our study aligns with the work done by Day and Bassuk (1994) that showed that callery pear (Pyrus calleryana 'Redspire') in compacted soil grew best with amendment as long as drainage was adequate.

Previous amendment studies neglected to measure initial soil-limiting characteristics. In most cases, researchers merely assumed that the soils to be amended were disturbed and had root-restricting properties. By contrast, in this study, we used soil samples that had known limiting properties, including bulk density above root-restricting thresholds and low percolation rates.

This investigation showed that the bulk density and macroporosity of two disturbed soil types, sandy loam and clay loam, were positively affected through amendation with organic matter. Bulk density decreased below root-restricting thresholds and macroporosity increased significantly. Modification of the soils with food waste compost and peat could be expected to reduce root impedance and increase soil aeration and drainage. The addition of organic amendment to a compacted soil increases the potential for better root growth even after soil is recompacted.

\section{LITERATURE CITED}

Aubertin, G.M., and L.T. Kardos. 1965. Root growth through porous media under controlled conditions. Soil Science of America Proceedings 29:290-293.

Brady, N.C. 1990. The Nature and Properties of Soils. Macmillan Publishing Co., New York, NY. 639 pp.

Corley, W.L. 1984. Soil amendments at planting. Journal of Environmental Horticulture 2:27-30.

Craul, P.J. 1985. A description of urban soils and their desired characteristics. Journal of Arboriculture 11: 330-339. 
1992. Urban Soil in Landscape Design. John Wiley and Sons, Inc., New York, NY. 396 pp.

Daddow, R.L., and G.E. Warrington. 1983. Growth-limiting bulk densities as influenced by soil texture. WSDG Report WSDG-TN-00005 Watershed Systems Development Group, USDA Forest Service.

Day, S.D., and N.L. Bassuk. 1994. Effects of four compaction remediation methods for landscape trees on soil aeration, mechanical impedance and tree establishment. Journal of Environmental Horticulture 13:64-71.

Hodge, S.J. 1995. The effect of seven organic amendments on planting pit soil and tree performance. ISSN 0307-1375 19(3).

Pellet, H. 1971. Effect of soil amendments on growth of landscape plants. American Nurseryman 134:103-106.

Spomer, L.A. 1983. Physical amendment of landscape soils. Journal of Environmental Horticulture 1:77-80.

Whitcomb, C.E. 1979. Factors affecting establishment of trees. Journal of Arboriculture 5:217-220.

Angela Rivenshield (corresponding author)

Cornell University

134A Plant Science Bldg.

Ithaca, NY 14853, U.S.

arivenshield@gmail.com

Nina Bassuk

Director

Urban Horticulture Institute

Cornell University

134A Plant Science Bldg.

Ithaca, NY 14853, U.S.

nlb2@cornell.edu

Résumé. Des échantillons de loam sablonneux et de loam argileux compactés ont été amendés avec de la matière organiquemousse de sphaigne ou compost d'ordures ménagères. Les amende- ments ont été incorporés aux échantillons de sol à des taux de $0 \%$, $10 \%, 33 \%, 50 \%$ et $75 \%$ sur une base de volume par volume. Les modifications en regard de la densité et de la macroporosité provenant de l'amendement ont été mesurées. Dans tous les types d'amendements sauf un, la macroporosité s'est accrue et la densité a diminué, et ce jusque sous le seuil de restriction pour les racines. Ces résultats sont demeurés vrais pour la moitié des échantillons qui ont été compactés manuellement à nouveau par la suite. Les différences entre les différents amendements n'étaient pas significatives. L'amendement avec une quantité suffisante de mousse de sphaigne ou de compost d'ordures ménagères diminue la compaction, ce qui crée un environnement plus favorable à la croissance des racines.

Zusammenfassung. Proben von verdichtetem sandigen Lehm und tonigem Lehmboden wurden angereichert mit organischer Substanz: Sphagnum Torf oder Lebensmittel-Kompost. Die Anreicherungen wurden in die Bodenproben auf einer Volumenbasis von $0 \%, 10 \%, 33 \%, 50 \%$ und $75 \%$ eingearbeitet. Die Veränderungen in der Bodenkörperdichte und Makroporosität resultierend aus der Anreicherung wurden gemessen. In jeder Permutation bis auf eine Aufnahme stieg die Makroporosität, während die Körperdichte unterhalb von Wurzelhaltefähigkeit fiel. Diese Ergebnisse trafen auf die Hälfte der Proben zu, die manuell nach-verdichtet wurden. Unterschiede zwischen den Anreicherungen waren nicht signifikant. Anreicherungen mit ausreichenden Mengen an Sphagnum Torf oder Lebensmittelkompost verringert die Verdichtung und erschafft verbesserte Bedingungen für Wurzelwachstum.

Resumen. Se mejoraron muestras de suelo franco-arenoso y franco-arcilloso con materia orgánica: sphagnum peat o composta. Los compuestos fueron incorporados a las muestras de suelo a $0 \%$, $10 \%, 33 \%, 50 \%$, y $75 \%$ con base en volumen -a- volumen. Se midieron los cambios en densidad real y macroporosidad resultantes del mejoramiento. En cada permutación, la porosidad incrementó, y la densidad real disminuyó en la zona de crecimiento de las raíces. Estos resultados fueron ciertos para la mitad de las muestras que fueron re-compactadas manualmente. Las diferencias entre los compuestos no fueron significativas. El mejoramiento con cantidades suficientes de sphagnum peat o composta reduce la compactación, creando un ambiente más propicio para el crecimiento de las raíces. 